\title{
Effect of Tunicamycin on Exo-1,3- $\beta$-D-glucanase Synthesis and Secretion by Cells and Protoplasts of Saccharomyces cerevisiae
}

\author{
By ANGELES SÁNCHEZ, JULIO R. VILLANUEVA AND \\ TOMAS G. VILLA* \\ Department of Microbiology, Faculty of Biology and C.S.I.C., University of Salamanca, Spain
}

(Received 8 December 1981; revised 4 May 1982)

\begin{abstract}
Addition of tunicamycin to the culture medium of growing Saccharomyces cerevisiae protoplasts or cells resulted in the formation of a modified exo-1,3- $\beta$-D-glucanase which was detectable in both extracellular and intracellular fractions. This modified enzyme had a lower molecular weight than the native form and did not bind to concanavalin A. The activation energy and $K_{\mathrm{m}}$ values of both enzyme forms were identical. Antibodies raised against the native protein readily precipitated the exo-1,3- $\beta$-D-glucanase produced after tunicamycin treatment. The latter enzyme was comparable, in terms of molecular size and lack of affinity for concanavalin $A$, to the $\beta$-D-glucanase obtained by treatment of the native form with endoglycosidase $\mathrm{H}$; both lacked the carbohydrate moiety present in the native enzyme. The exo-1,3- $\beta$-D-glucanase obtained in the presence of the antibiotic was more sensitive to variations in temperature and $\mathrm{pH}$ than both endoglycosidase $\mathrm{H}$-treated and non-treated enzymes. Our results suggest that the carbohydrate moiety, if not necessary for exo-1,3- $\beta$-D-glucanase secretion, may play a role in the conformation of the protein and in stabilizing the enzymic activity.
\end{abstract}

\section{INTRODUCTION}

1,3- $\beta$-D-Glucanases are widely distributed among micro-organisms (Villanueva et al., 1976). They may be classified as exo- (EC 3.2.1.56) or endo-1,3- $\beta$-D-glucanases (EC 3.2.1.6). The former give only D-glucose as the end product of $1,3-\beta$-D-glucan hydrolysis, whereas the latter produce a mixture of laminaridextrins, mainly laminaritriose and laminaribiose, with D-glucose as a minor end product. Both types of enzyme forms are easily detected in extracellular and intracellular fractions of actively growing cells and protoplasts of Saccharomyces cerevisiae (Farkas et al., 1973).

It has been reported (Notario et al., 1976; Villa et al., 1978a) that yeast $\beta$-D-glucanases are glycoproproteins. These enzymes may be a good system for studying the role of the carbohydrate moiety during the synthesis and secretion of glycoproteins, and we have now approached this problem by using tunicamycin. This antibiotic is known to prevent the synthesis of dolichol pyrophosphate- $N$-acetylglucosamine, which represents the first step in the pathway of biosynthesis of glycoproteins containing the $\mathrm{N}$-acetylglucosaminoyl type of bond (Takatsuki et al., 1971; Tkacz \& Lampen, 1975). Treatment with tunicamycin in vivo produces under- or nonglycosylated proteins in both animal cells and in eukaryotic micro-organisms (Olden et al., 1978). A similar modification can be obtained by treating glycoproteins in vitro with the enzyme endoglycosidase $\mathrm{H}$. Endo $\mathrm{H}$ (endo- $\beta$ - $N$-acetylglucosaminidase $\mathrm{H}$; EC 3.2.1.96) from Streptomyces griseus cleaves the bond between the two $\mathrm{N}$-acetylglucosamine residues of the core oligosaccharides in the high-mannose type of glycoproteins (Tarentino et al., 1974).

We describe in the present paper how, by using tunicamycin or endo $\mathrm{H}$, we obtained an underglycosylated form which was still active but showed different responses to temperature and $\mathrm{pH}$ as compared with the unmodified enzyme. These results allow us to conclude that total

Abbreviations: Endo $\mathrm{H}$, endo- $\beta$ - $N$-acetylglucosaminidase; PNPG, $p$-nitrophenyl- $\beta$-D-glucanopyranoside. 
glycosylation, if not critical for exo- $\beta$-glucanase secretion, may be essential for stability and for maintaining full catalytic activity and also for attaining the correct conformation.

\section{METHODS}

Strain and growth conditions. Saccharomyces cerevisiae strain ts ${ }^{-136}$ Mel0 was used throughout the present work (Sánchez et al., 1980). Stock cultures were grown in slant tubes with a solid medium containing $20 \mathrm{~g}$ agar, $20 \mathrm{~g}$ glucose and $10 \mathrm{~g}$ Difco yeast extract $\mathrm{l}^{-1}$. Liquid media contained $10 \mathrm{~g}$ galactose and $10 \mathrm{~g}$ yeast extract $\mathrm{l}^{-1}$ (YEGal). The cultures were incubated aerobically in a rotatory shaker $(240$ r.p.m. $)$ at $24^{\circ} \mathrm{C}$.

Conversion of cells into protoplasts, preparations of the enzyme and reaction with concanavalin $A$. These were performed as previously described (Sánchez et al., 1980).

Exo-1,3- $\beta$-D-glucanase activity determinations. $\beta$-Glucanase activity was assayed on laminarin, periodateoxidized laminarin, pustulan and $p$-nitrophenyl- $\beta$-D-glucopyranoside (PNPG). Reducing sugars and $p$-nitrophenol liberated were measured as described by Notario et al. (1976). One unit of activity (U) was defined as the amount of enzyme which released $1 \mu \mathrm{mol}$ of $p$-nitrophenol, glucose or equivalent reducing power $\mathrm{h}^{-1}$ at $30^{\circ} \mathrm{C}$.

When $4^{\prime}$-methylumbellipheryl- $\beta$-D-glucoside was employed as the substrate, the exo- $\beta$-glucanase activity was detected by illumination under UV light $(254 \mathrm{~nm})$.

Crude enzyme preparation. Saccharomyces cerevisiae was grown at $24^{\circ} \mathrm{C}$ on galactose as the carbon source for $36 \mathrm{~h}$ (cell density $3 \mathrm{mg} \mathrm{ml}^{-1}$ ). After harvesting by centrifugation, the supernatant ( $83 \mathrm{l}$ ) was adjusted to a $\mathrm{pH}$ value of 7.0 and the enzyme adsorbed on $25 \mathrm{~g}$ DEAE-Sephadex A-50 in a batchwise manner. The supernatant was removed by filtration and discarded. The exo- $\beta$-glucanase was then eluted from the gel with $0 \cdot 1 \mathrm{M}$-sodium acetate buffer ( $\mathrm{pH}$ 5.2) containing $1 \mathrm{M}-\mathrm{NaCl}$, and used in subsequent purification steps.

Anion exchange chromatography. The samples were applied to a DEAE-Bio Gel column $(31 \times 3 \mathrm{~cm})$ previously equilibrated with $0.05 \mathrm{M}$-Tris/ $\mathrm{HCl}$ buffer $(\mathrm{pH} 7 \cdot 3$ ). The column was washed with the same buffer until all the unadsorbed protein was removed. Exo- $\beta$-glucanase was then eluted with an $\mathrm{NaCl}$ gradient (up to $1 \mathrm{M}$ ).

Concanavalin $A$-Sepharose $4 B$ chromatography. The samples were applied to a column $(24.5 \times 2.5 \mathrm{~cm})$ packed with concanavalin A-Sepharose 4B previously equilibrated with $0 \cdot 1 \mathrm{M}$-sodium acetate buffer ( $\mathrm{pH} 6 \cdot 0$ ). The elution of both unadsorbed and adsorbed proteins was accomplished by washing first with $200 \mathrm{ml}$ of the same buffer followed by buffer supplemented with $7 \%(\mathrm{w} / \mathrm{v})$ methyl- $\alpha$-D-mannoside, as specified by Lloyd (1970).

Gel exclusion chromatography. Gel exclusion chromatography was carried out on columns $(92 \times 2.5 \mathrm{~cm} ; 89 \times$ $2.8 \mathrm{~cm}$ ) packed, respectively, with Sephacryl S-200 and Sephacryl S-300. The columns were previously equilibrated with $0 \cdot 1 \mathrm{M}$-sodium acetate buffer $\left(\mathrm{pH} \mathrm{5 \cdot 2)}\right.$ and the samples eluted at a flow rate of $30 \mathrm{ml} \mathrm{h}^{-1}$. Fractions $(5 \mathrm{ml})$ were collected. The elution of exo-1,3- $\beta$-D-glucanase is referred to throughout this paper as a value indicating the ratio $V_{\mathrm{e}} / V_{0}$ where $V_{\mathrm{e}}$ and $V_{0}$ are the volumes at which the enzyme and Dextran Blue 2000 eluted from the columns, respectively.

PAGE, isoelectric focusing, sedimentation analysis, enzyme hydrolysis, amino acid analysis, paper and gas-liquid chromatography and analytical measurements. These were all performed as described by Notario et al. (1976). Staining of glycoproteins was carried out by the Schiff-PAS method according to Zaccharius et al. (1969).

Activation energy and $K_{m}$ values. These were estimated as described by Villa et al. $(1978 b)$.

Removal of carbohydrate from exo- $\beta$-glucanase by endo $H$ treatment. Endo $\mathrm{H}(0.01 \mathrm{U})$ was added to purified exo1,3- $\beta$-glucanase ( $0.4 \mathrm{mg}$ protein) in $0.1 \mathrm{M}$-acetate buffer ( $\mathrm{pH} \mathrm{5.2)} \mathrm{which} \mathrm{contained} 0.05 \% \mathrm{NaN}_{3}$, and incubated for $30 \mathrm{~h}$ at $33^{\circ} \mathrm{C}$. More endo $\mathrm{H}(0.01 \mathrm{U})$ was added to the underglycosylated enzyme and incubated again under the same conditions.

$\beta$-Elimination reaction. This was performed as described by Aminoff et al. (1980).

Stability tests. Stability assays were performed by keeping enzyme solutions $\left(30 \mu \mathrm{g} \mathrm{ml}{ }^{-1}\right)$ at different temperatures (from 45 to $55^{\circ} \mathrm{C}$ ) at a pH value of 3.1 and then measuring the residual activities. Trypsin ( $300 \mu \mathrm{g}$ $\mathrm{ml}^{-1}$ ) (Sigma) was added to enzyme dilutions in $0 \cdot 1 \mathrm{M}$-Tris/ $\mathrm{HCl}$ buffer $\left(\mathrm{pH} 7 \cdot 5\right.$ ) and incubated at $30^{\circ} \mathrm{C}$ for $90 \mathrm{~min}$. Samples were taken at different times and trypsin inhibitor (Sigma) was used to stop the proteolytic action. The samples were assayed for residual exo- $\beta$-glucanase activity.

Immunological methods. Anti-exo-1,3- $\beta$-D-glucanase serum was obtained by immunizing rabbits with purified enzyme $(1.59 \mathrm{mg})$. The enzymic protein was injected in two doses in a three week period. Antibodies were prepared by $\left(\mathrm{NH}_{4}\right)_{2} \mathrm{SO}_{4}$ precipitation and immunoprecipitation experiments were performed at $4{ }^{\circ} \mathrm{C}$ for $20 \mathrm{~h}$. The antibody specificity was tested by double-diffusion Ouchterlony assays and by immunoelectrophoresis (Garvey et al., 1977). The antigen-antibody complex was hydrolysed and PAGE of the products revealed only two protein bands which corresponded to immunoglobulin $\mathrm{G}$ and the exo- $\beta$-glucanase. Two-dimensional immunoelectrophoresis was performed as described by Laurell (1966).

Radioactive labelling of exo- $\beta$-glucanase. The exo- $\beta$-glucanase synthesis was determined by measuring the incorporation of $\left[{ }^{14} \mathrm{C}\right]$ serine into antibody-precipitable enzyme. Protoplasts or cells $\left(3 \mathrm{mg} \mathrm{ml}^{-1}\right)$ were incubated in $40 \mathrm{ml} \mathrm{YEGal} \mathrm{medium} \mathrm{and} 10 \mu \mathrm{Ci}$ of $\mathrm{L}-\left[\mathrm{U}-{ }^{14} \mathrm{C}\right]$ serine (sp. act. $8 \mathrm{GBq} \mathrm{mmol}^{-1}$; Amersham) were added. Samples (5 
$\mathrm{ml})$ were taken at different times, precipitated with anti-exo- $\beta$-glucanase antibodies $(10 \mu \mathrm{g})$ and filtered on GF/C Whatman discs; the radioactivity on the discs was counted in a Packard scintillation spectrometer.

Incorporation of $\left[{ }^{14} \mathrm{C}\right]$ mannose into antibody-precipitable enzyme was carried out by incubating $410 \mathrm{mg}$ (dry wt) protoplasts in $140 \mathrm{ml}$ culture medium which was supplemented with $12 \mu \mathrm{Ci} \mathrm{D}-\left[\mathrm{U}-{ }^{1+} \mathrm{C}\right] \mathrm{mannose}$ (sp. act. $11 \cdot 1 \mathrm{GBq} \mathrm{mmol}^{-1}$; Amersham). Samples $(5 \mathrm{ml})$ were then removed at different intervals, processed and counted as described above.

Chemicals. Tunicamycin was kindly supplied by Dr R. L. Hamill (Lilly Research Laboratory, Division of Eli Lilly, Indianapolis, Ind., U.S.A.). Sephacryl S-200, Sephacryl S-300, DEAE-Sephadex A-50, concanavalin ASepharose $4 B$ and Blue Dextran 2000, were obtained from Pharmacia. DEAE-Bio Gel A was purchased from Bio Rad and endo H from Seikagaku Fine Biochemicals, Tokyo, Japan. Concanavalin A, p-nitrophenol, PNPG, 4'methylumbellipheryl- $\beta$-D-glucoside, cellobiose, and salicin were obtained from Sigma. Laminarin was purchased from Koch-Light and periodate-oxidized laminarin was prepared by the method of Goldstein et al. (1965). Pustulan was obtained from Calbiochem. All other reagents were of analytical grade from commercial sources.

\section{RESULTS}

Exo-1,3- $\beta$-D-glucanase production by $S$. cerevisiae cells with and without tunicamycin

Addition of tunicamycin to growing cells provoked an increase in the exo-1,3- $\beta$-D-glucanase activity detectable in both the supernatant and cell-associated enzyme preparations (Fig. 1), although under these conditions, growth was reduced to a certain extent. Fractionation of samples from the tunicamycin-treated culture showed the existence of two peaks corresponding to the native enzyme and a new enzymic form which proved to be underglycosylated.

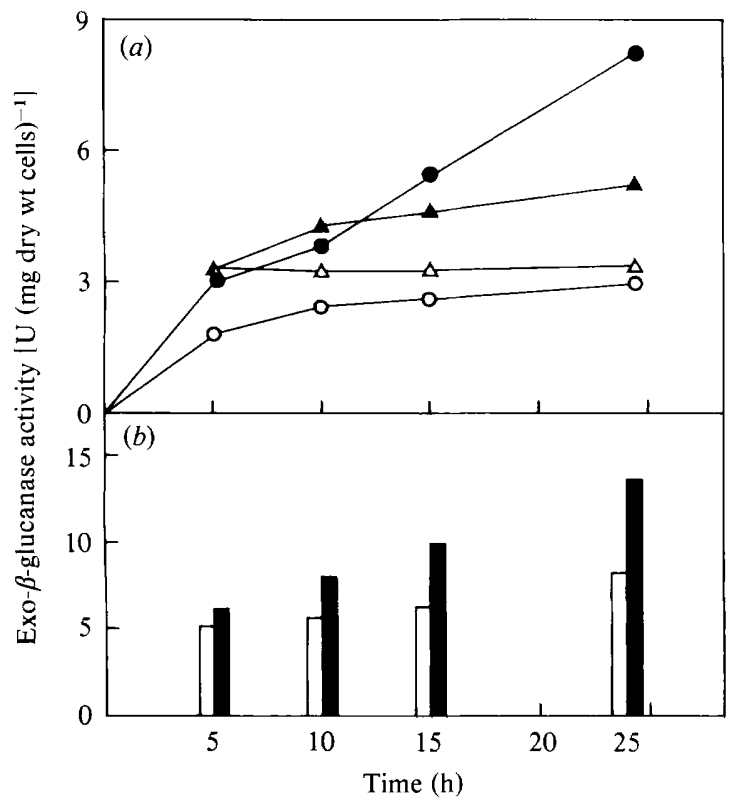

Fig. 1

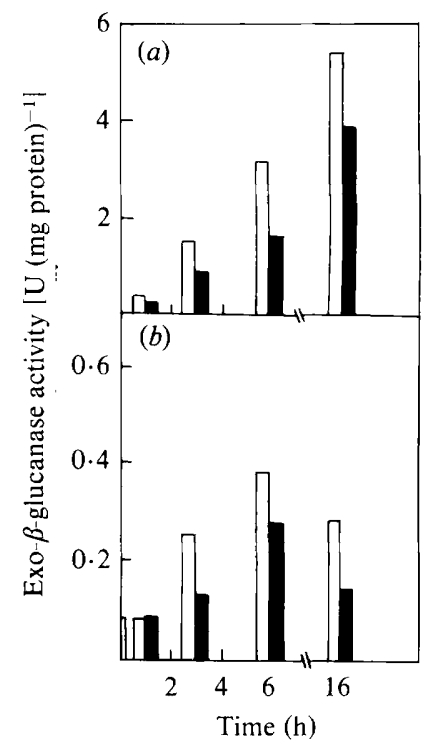

Fig. 2

Fig. 1. Effect of tunicamycin $\left(30 \mu \mathrm{g} \mathrm{ml}^{-1}\right)$ on exo-1,3- $\beta$-D-glucanase production. (a) Enzyme activity in extracellular fractions of $S$. cerevisiae cells growing in the absence $(O)$ or presence $(O)$ of tunicamycin; intracellular enzyme activity in samples without $(\triangle)$ and with $(\mathbf{\Delta})$ antibiotic. $(b)$ Total exo- $\beta$ glucanase activity in control (open bars) and tunicamycin-treated (filled bars) cultures.

Fig. 2. Effect of tunicamycin $\left(30 \mu \mathrm{g} \mathrm{ml}^{-1}\right)$ on extracellular $(a)$ and intracellular $(b)$ exo-1,3- $\beta$-Dglucanase production. Enzyme activity during protoplast regeneration in medium without (open bars) and with (filled bars) tunicamycin was measured. 
Incorporation of $\left[{ }^{14} \mathrm{C}\right]$ serine into antibody-precipitable exo- $\beta$-glucanase showed that, although the enzyme activity secreted by $S$. cerevisiae cells was higher in the antibiotic-treated samples, there was not an increase in the amount of immunoprecipitated enzyme.

\section{Effect of tunicamycin on exo-1,3- $\beta$-D-glucanase production by protoplasts}

Addition of tunicamycin $\left(30 \mu \mathrm{g} \mathrm{ml}^{-1}\right)$ to the incubation medium of $S$. cerevisiae protoplasts lowered the exo- $\beta$-glucanase activity (Fig. 2 ). Higher concentrations of the antibiotic (up to 90 $\mu \mathrm{g} \mathrm{m}^{-1}$ ) did not totally stop the production of exo-1,3- $\beta$-D-glucanase. Tunicamycin did not affect the incorporation of $\left[{ }^{14} \mathrm{C}\right]$ threonine into total TCA-precipitable material (Sánchez et al., 1980 ). When the exo-1,3- $\beta$-D-glucanase activity was subjected to gel exclusion chromatography through Sephacryl S-200, a new enzyme form appeared in both intracellular (Fig. 3) and extracellular (Fig. 4) fractions of protoplasts growing in the presence of the antibiotic. This new enzyme eluted from the columns with a $V_{\mathrm{e}} / V_{0}$ value of 1.81 , whereas this value for the native exo-1,3- $\beta$-D-glucanase was $1 \cdot 58$.

\section{Exo-1,3- $\beta$-D-glucanase purification, characterization and enzyme composition}

Purification of exo-1,3- $\beta$-D-glucanase from culture media of $S$. cerevisiae was accomplished by the steps indicated in Table 1 . The increase in enzyme activity shown in the last purification step could be explained by the elimination of an inhibitor or modification in the protein structure. Such an activation occurs in some hydrolytic enzymes and usually depends on physico-chemical conditions (Villa et al., 1978b).

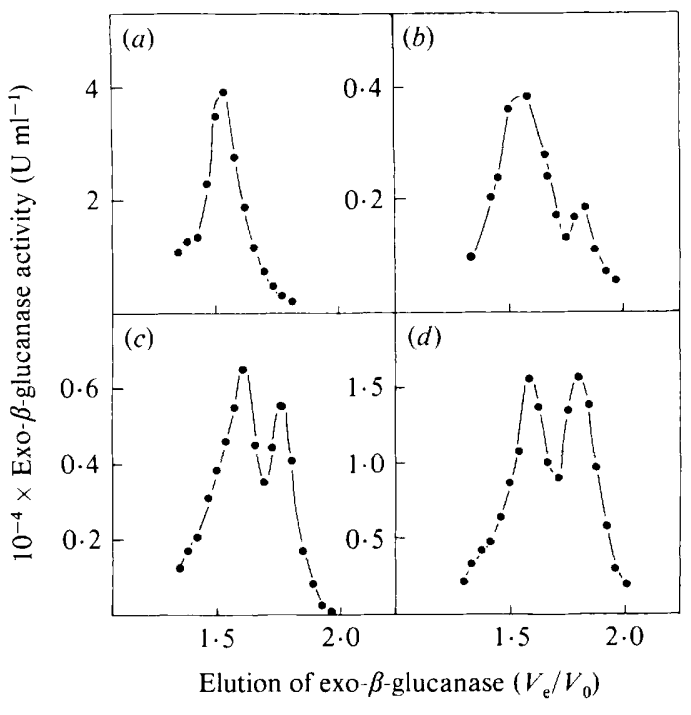

Fig. 3

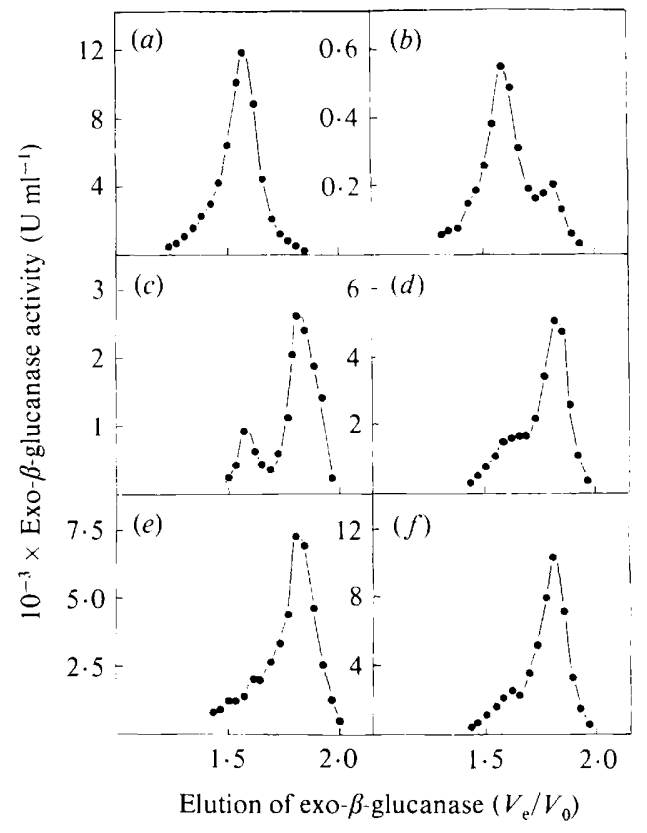

Fig. 4

Fig. 3. Gel exclusion chromatography through Sephacryl S-200 of the exo-1,3- $\beta$-D-glucanases from intracellular fractions of $S$. cerevisiae protoplasts. Samples were incubated in the absence $(a)$ or presence $(b, c, d)$ of tunicamycin $\left(30 \mu \mathrm{g} \mathrm{ml}^{-1}\right)$. Incubation times: $8 \mathrm{~h}(a, d), 1 \mathrm{~h}(b)$ and $6 \mathrm{~h}(c)$. The elution of exo1,3- $\beta$-D-glucanase is represented by $V_{\mathrm{e}} / V_{0}$, where $V_{\mathrm{e}}$ and $V_{0}$ are the volumes at which the enzyme and Dextran Blue 2000 eluted from the columns, respectively.

Fig. 4. Gel exclusion chromatography through Sephacryl S-200 of exo-1.3- $\beta$-D-glucanases present in the supernatant medium of growing $S$. cerevisiae protoplasts. Regenerating protoplasts were incubated in the absence $(a)$ or in the presence $(b-f)$ of tunicamycin $\left(30 \mu \mathrm{g} \mathrm{ml}^{-1}\right)$. Incubation times: $6 \mathrm{~h}(a), 1 \mathrm{~h}(b)$, $3 \mathrm{~h}(c), 6 \mathrm{~h}(d), 8 \mathrm{~h}(e)$ and $16 \mathrm{~h}(\mathrm{f})$. The elution of exo-1,3- $\beta$-D-glucanase is represented by $V_{\mathrm{e}} / V_{0}$ (see legend to Fig. 3). 
Table 1. Purification of exo-1,3- $\beta$-D-glucanase from $S$. cerevisiae strain ts ${ }^{-136}$ Me10

\begin{tabular}{|c|c|c|c|c|c|c|}
\hline Purification step & $\underset{(\mathrm{ml})}{\text { Volume }}$ & $\begin{array}{c}\text { Total activity } \\
\text { (U) }\end{array}$ & $\begin{array}{l}\text { Total protein } \\
\quad(\mathrm{mg})\end{array}$ & $\begin{array}{c}10^{-2} \times \text { Specific activity } \\
{\left[\mathrm{U}(\mathrm{mg} \text { protein })^{-1}\right]}\end{array}$ & $\begin{array}{l}\text { Purification } \\
\quad \text { (fold) }\end{array}$ & $\begin{array}{c}\text { Yield } \\
(\%)\end{array}$ \\
\hline Culture medium & 83375 & 181 & 107386 & $0 \cdot 17$ & - & 100 \\
\hline DEAE-Sephadex & 1280 & 134 & 3180 & 0.42 & $2 \cdot 5$ & 73.8 \\
\hline $\begin{array}{c}\text { A-50 adsorption } \\
\text { DEAE-Bio Gel A } \\
\text { chromatography }\end{array}$ & 11.9 & $90 \cdot 4$ & 227 & 39.8 & 234 & 49.9 \\
\hline $\begin{array}{l}\text { Concanavalin A- } \\
\text { Sepharose } 4 \mathrm{~B} \\
\text { chromatography }\end{array}$ & $4 \cdot 2$ & $56 \cdot 4$ & 120 & 47 & 276 & $31 \cdot 1$ \\
\hline $\begin{array}{l}\text { Sephacryl S-200 } \\
\text { chromatography }\end{array}$ & $3 \cdot 2$ & $22 \cdot 3$ & 23 & 98 & 578 & $12 \cdot 3$ \\
\hline $\begin{array}{l}\text { Sephacryl S-300 } \\
\text { chromatography }\end{array}$ & 3.5 & $61 \cdot 8$ & $7 \cdot 8$ & 792 & 4661 & $34 \cdot 1$ \\
\hline
\end{tabular}

Table 2. Amino acid composition of the purified exo-1,3- $\beta$-D-glucanase from $S$. cerevisiae

\begin{tabular}{lcc} 
& \multicolumn{2}{c}{ Composition } \\
\cline { 2 - 3 } Amino acid & [nmol (mg protein $\left.)^{-1}\right]$ & $\%$ \\
Aspartic acid & 26 & $0 \cdot 6$ \\
Threonine & 266 & $6 \cdot 4$ \\
Serine & 402 & $9 \cdot 7$ \\
Glutamic acid & 533 & $12 \cdot 9$ \\
Glutamine & 4 & $0 \cdot 1$ \\
Proline & 45 & $1 \cdot 1$ \\
Glycine & 574 & $13 \cdot 9$ \\
Alanine & 308 & $7 \cdot 4$ \\
Valine & 276 & $6 \cdot 7$ \\
Cysteine & 254 & $6 \cdot 1$ \\
Methionine & 65 & $1 \cdot 6$ \\
Isoleucine & 134 & $3 \cdot 3$ \\
Leucine & 336 & $8 \cdot 1$ \\
Tyrosine & 141 & $3 \cdot 4$ \\
Phenylalanine & 96 & $2 \cdot 3$ \\
Lysine & 588 & $14 \cdot 2$ \\
Histidine & 79 & $1 \cdot 9$ \\
Arginine & 7 & $0 \cdot 2$
\end{tabular}

The purity of the enzyme was checked by PAGE. Three gels were run; the first was stained directly for protein and the second for glycoprotein. The third was cut into $1 \mathrm{~mm}$ slices and tested for exo-1,3- $\beta$-D-glucanase activity. In all cases only one band was detected after the last purification step. Protein, glycoprotein and exo-1,3- $\beta$-D-glucanase activity were detected at the same distance from the origin of the gels. The purified enzyme sedimented as a single protein when ultracentrifugation was used to check the purity. The estimated sedimentation coefficient $\left(s_{20, w}\right)$ was $5 \cdot 4 \mathrm{~S}$. Immunological criteria such as two-dimensional immunoelectrophoresis (Fig. 5) also confirmed the purity of the exo-1,3- $\beta$-D-glucanase.

The purified enzyme was characterized as belonging to the exo-splitting type of $\beta$-glucanases by its ability to hydrolyse $p$-nitrophenyl- $\beta$-D-glucopyranoside, production of glucose as the only end product of laminarin hydrolysis and by its lack of activity of cellobiose, salicin, and periodate-oxidized laminarin. Studies using different substrates showed that the enzyme was an unspecific exo- $\beta$-glucanase able to hydrolyse both $\beta-(1,3)$ and $\beta-(1,6)$ glycosidic linkages.

Samples of purified enzyme were hydrolysed ; descending paper chromatography and gasliquid chromatography of the neutral sugar solution obtained revealed that $70 \%$ of the total carbohydrate was mannose, whereas the percentages of glucose and glucosamine were 25 and $5 \%$, respectively. Tunicamycin and endo $\mathrm{H}$ effects were taken as evidence that the oligosaccharides were linked to the polypeptide by $\mathrm{N}$-glycosidic bonds: this was confirmed by the negative results obtained by $\beta$-elimination experiments.

The amino acid analysis is shown in Table 2 . 

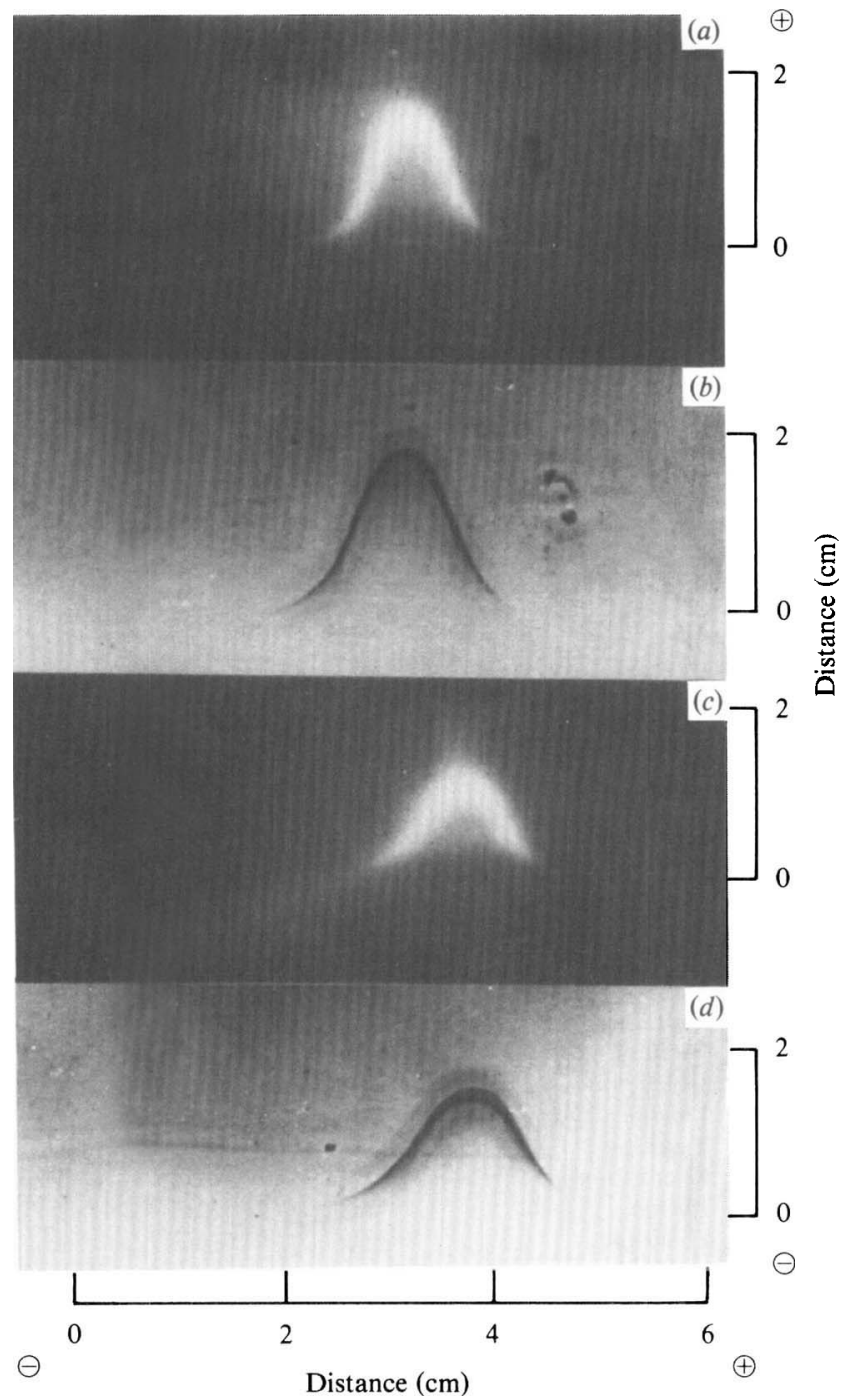

Fig. 5. Two-dimensional immunoelectrophoresis of the exo-1,3- $\beta$-D-glucanase purified from $S$. cerevisiae. Enzyme activity on $4^{\prime}$-methyl-umbellipheryl- $\beta$-D-glucoside $(a, c)$ and protein staining $(b, d)$; $(a, b)$ and $(c, d)$ correspond to different electrophoretic runs with 1.5 and $1 \cdot 1 \mu \mathrm{g}$ of antigen, respectively.

\section{Characterization of the underglycosylated form}

The underglycosylated glucanase obtained upon treatment of growing cells or protoplasts with tunicamycin was characterized as belonging to the exo-splitting type by its ability to hydrolyse $p$ nitrophenyl- $\beta$-D-glucopyranoside, production of glucose as the only end product of laminarin hydrolysis and by its inability to hydrolyse periodate-oxidized laminarin. It was also found that the activation energy $\left(E_{\mathrm{a}}=23.4 \times 10^{3} \mathrm{~J} \mathrm{~mol}^{-1}\right.$ with laminarin; $E_{\mathrm{a}}=22.2 \times 10^{3} \mathrm{~J} \mathrm{~mol}^{-1}$ with PNPG) and $K_{\mathrm{m}}$ values (4.04 mM with PNPG) of the underglycosylated form were identical to those of the native enzyme and also very close to those of the same glucanase purified from culture media $\left(E_{\mathrm{a}}=23.0 \times 10^{3} \mathrm{~J} \mathrm{~mol}^{-1}\right.$ with laminarin; $E_{\mathrm{a}}=21.7 \times 10^{3} \mathrm{~J} \mathrm{~mol}^{-1}$ with PNPG; $K_{\mathrm{m}}=4.07 \mathrm{~mm}$ with PNPG). In addition, antibodies prepared against the latter enzyme readily precipitated both native and underglycosylated exo- $\beta$-glucanases.

The molecular weights for both native and underglycosylated enzymes were estimated to be 58800 and 43000 , respectively. 
Table 3. Exo- $\beta$-glucanase activity and incorporation of $\left[{ }^{14} \mathrm{C}\right]$ serine into immunoprecipitated enzyme in intracellular and extracellular fractions of growing $S$. cerevisiae protoplasts

Samples were incubated for various times with and without tunicamycin $\left(30 \mu \mathrm{g} \mathrm{ml}^{-1}\right)$ and then exo- $\beta$ glucanase activity and radioactivity incorporated into immunoprecipitated material were measured.

\begin{tabular}{|c|c|c|c|c|c|}
\hline \multirow[b]{2}{*}{ Fraction } & \multirow[b]{2}{*}{$\begin{array}{l}\text { Incubation } \\
\text { time (h) }\end{array}$} & \multicolumn{2}{|c|}{$\begin{array}{l}\text { Exo- } \beta \text {-glucanase activity } \\
\qquad\left(\mathrm{U} \mathrm{ml} \mathrm{l}^{-1}\right)\end{array}$} & \multicolumn{2}{|c|}{ Radioactivity (c.p.m.) } \\
\hline & & Control & $\overbrace{\text { With tunicamycin }}$ & Control & With tunicamycin \\
\hline Intracellular & $\begin{array}{l}2 \\
4 \\
6\end{array}$ & $\begin{array}{l}0.048 \\
0.079 \\
0.099\end{array}$ & $\begin{array}{l}0.029 \\
0.041 \\
0.065\end{array}$ & $\begin{array}{l}122 \\
185 \\
289\end{array}$ & $\begin{array}{r}75 \\
98 \\
194\end{array}$ \\
\hline Extracellular & $\begin{array}{l}2 \\
4 \\
6\end{array}$ & $\begin{array}{l}0 \cdot 230 \\
0 \cdot 455 \\
0 \cdot 815\end{array}$ & $\begin{array}{l}0.165 \\
0.390 \\
0.685\end{array}$ & $\begin{array}{l}342 \\
408 \\
650\end{array}$ & $\begin{array}{l}240 \\
352 \\
582\end{array}$ \\
\hline
\end{tabular}

The native form was readily precipitated by concanavalin $\mathrm{A}$, whereas $95 \%$ of the underglycosylated protein remained in the supernatant under the same conditions.

\section{Stability of the native and underglycosylated exo- $\beta$-glucanases}

Both native and underglycosylated enzyme forms were treated under extreme $\mathrm{pH}$ and thermal conditions and were also incubated with proteases in order to establish whether there were any difference between the exo-1,3- $\beta$-D-glucanases produced in the absence or presence of tunicamycin.

The glycosylated enzyme treated at $45^{\circ} \mathrm{C}$ for $45 \mathrm{~min}$ maintained full activity, whereas the activity of the underglycosylated form under the same conditions was lowered by about $35 \%$. In treatments of both enzymes at $\mathrm{pH} 3 \cdot 1$, the native glucanase showed in the first minute an initial loss of activity of only $5 \%$ and after $75 \mathrm{~min}$ at this $\mathrm{pH}$ value still retained $56 \%$ of the catalytic power. The underglycosylated form showed an initial loss of activity of $54 \%$ and only $7 \%$ remained after $75 \mathrm{~min}$.

The native enzyme incubated for $90 \mathrm{~min}$ in the presence of trypsin maintained $52 \%$ of its activity, whereas the residual one for the underglycosylated form after the same period was $86 \%$.

\section{Incorporation of $\left[{ }^{14} \mathrm{C}\right]$ serine into antibody-precipitable exo- $\beta$-glucanase produced by $S$. cerevisiae protoplasts}

Tunicamycin seemed to act only on exo- $\beta$-glucanase synthesis (Table 3 ). The enzyme activity and the antibody-precipitated exo- $\beta$-glucanase (labelled with $\left[{ }^{14} \mathrm{C}\right]$ serine) were decreased to the same extent by the antibiotic in both intracellular and extracellular fractions. In all cases we were unable to detect an inactive enzyme form in intracellular or extracellular fractions.

\section{Effect of tunicamycin on the incorporation of $\left[{ }^{14} \mathrm{C}\right]$ mannose into antibody-precipitable exo- $\beta$-glucanase}

Samples of protoplasts growing in the presence or absence of tunicamycin were incubated with $\left[{ }^{14} \mathrm{C}\right]$ mannose. As was to be expected, the radioactivity incorporated into the antibodyprecipitable exo- $\beta$-glucanase was lower in the antibiotic-treated fractions (Fig. 6). In some of the control and tunicamycin samples a decrease was observed in the amount of antibodyprecipitated radioactivity, even though the enzyme activity had increased. This result points to the existence of glycohydrolases such as mannosidases, glucosidases or related enzymes which would remove the terminal sugars from the oligosaccharides linked to protein. Samples of the antibody-precipitated material were hydrolysed and descending paper chromatography of the neutral sugar solution revealed that essentially all the radioactivity migrated as mannose.

\section{Removal of carbohydrate from exo-1,3- $\beta$-D-glucanase}

Samples of the purified exo- $\beta$-glucanase were incubated with endo $H$. Although the enzyme activity was apparently unaffected, the treatment resulted in the formation of an 


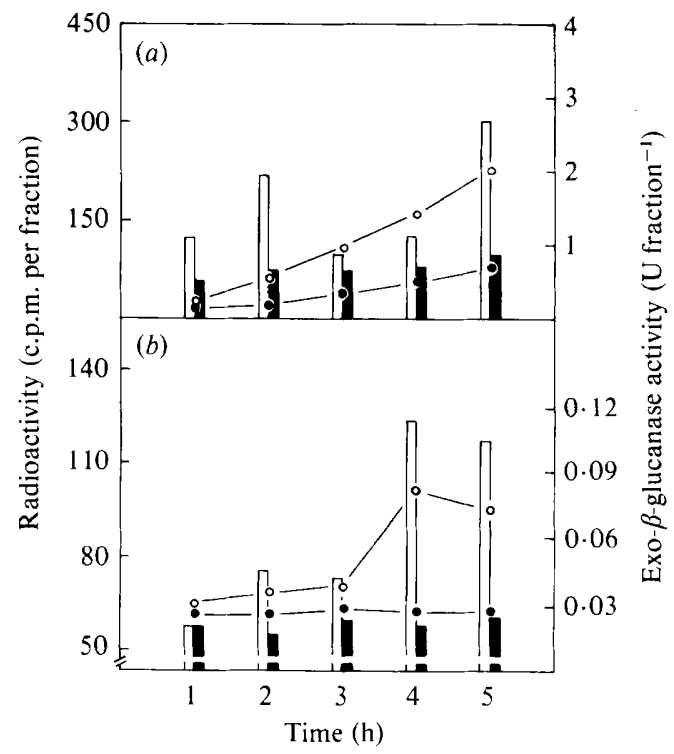

Fig. 6. Enzyme activity and $\left[{ }^{14} \mathrm{C}\right]$ mannose incorporation into the immunoprecipitated exo- $\beta$-glucanase from extracellular $(a)$ and intracellular $(b)$ fractions of growing protoplasts. Exo- $\beta$-glucanase activity in the absence $(O)$ or presence $(O)$ of tunicamycin was measured. Immunoprecipitated radioactivity in samples without (open bars) and with (filled bars) tunicamycin is shown.

underglycosylated form which exhibited a molecular weight value of 43000 by gel exclusion chromatography. The oligosaccharides released by the deglycosylating enzyme eluted as a single peak in Sephacryl S-200 chromatography; upon hydrolysis this yielded mannose, glucose and glucosamine.

The exo-1,3- $\beta$-D-glucanase was not completely depleted of its carbohydrate by the endo $\mathrm{H}$ treatment, since the underglycosylated enzyme was weakly stained by the Schiff-PAS staining method and the phenol-sulphuric reagent, although it lacked affinity towards concanavalin A. Both fully glycosylated and endo $\mathrm{H}$-treated purified exo-1,3- $\beta$-D-glucanases were incubated under extreme $\mathrm{pH}$ and thermal conditions in order to determine any difference in their stability. The two enzymes behaved in a very similar way although the residual activity maintained by the exo- $\beta$-glucanases under those conditions was slightly higher for the fully glycosylated form.

\section{DISCUSSION}

The results in this paper suggest that the carbohydrate moiety does not play a crucial role in the secretion of exo-1,3- $\beta$-D-glucanase of Saccharomyces cerevisiae. In the presence of tunicamycin, which specifically inhibits the formation of dolichol pyrophosphate- $N$-acetylglucosamine, we obtained an underglycosylated enzyme form. Such a protein was detectable in both extracellular and intracellular fractions of growing protoplasts and cells. It was nonprecipitable by the lectin concanavalin $A$. This was also found for the enzyme form obtained upon treatment of the purified native glucanase with endo $\mathrm{H}$.

The effects that tunicamycin and endo $\mathrm{H}$ exert on the enzyme suggest that in this glycoprotein the carbohydrate moiety is bound to the polypeptide chain through GlcNAc-Asn linkages and also that intermediate lipids participate in its synthesis. The reduction in molecular weight of the exo-1,3- $\beta$-D-glucanase obtained in the presence of either tunicamycin or endo $\mathrm{H}(13000 \pm 2000)$ may give an indication of the carbohydrate content linked through asparagine to the polypeptide chain (approx. 20\%).

It has been shown that in certain glycoproteins the carbohydrate moiety is indispensable for secretion of, for instance in the case of $S$. cerevisiae, invertase and acid phosphatase (Kuo \& Lampen, 1974) and in IR 162 plasma cells, immunoglobulin E (Hickman et al., 1977). The non- 
glycosylated precursors of influenze virus haemagglutinin synthesized in the presence of $D^{-}$ glucosamine, as well as the envelope proteins of Rauscher murine leukaemia virus obtained with tunicamycin, do not undergo further processing (Klenk et al., 1972; Schultz \& Oroszlan, 1979). In the case of cell surface protein (also known as LETS protein, or fibronectin) from chick embryo fibroblasts (Olden et al., 1978), haemagglutinin from fowl plague virus (Schwartz et al., 1976) and haemagglutinin from influenza virus (Schwarz \& Klenk, 1974) the effect of tunicamycin is such that the underglycosylated proteins have a higher sensitivity to proteolytic degradation.

In the case of exo-1,3- $\beta$-D-glucanase the interference with the glycosylation process does not arrest the synthesis and secretion of the enzyme, although the underglycosylated form is more affected than the native enzyme by changes in temperature and $\mathrm{pH}$.

The different behaviour of the enzymes in terms of detectable activity after addition of tunicamycin during synthesis may be due to the decreased carbohydrate content, as has been suggested in several reports in the literature. Thus, Hickman \& Kornfeld (1978) studied the effect of tunicamycin on the secretion of several immunoglobulins by mouse plasmacytoma cells and found that the degree of secretion was related to the carbohydrate content. Working with invertase and acid phosphatase from S. cerevisiae, Kuo \& Lampen (1974) were unable to detect either formation of active enzyme or intracellular accumulation in the presence of tunicamycin. There is a number of cases in which the addition of the antibiotic gives underglycosylated forms, an effect similar to the one described here for the exo-1,3- $\beta$-D-glucanase. Thus, such an effect has been reported for $S$. cerevisiae alkaline phosphatase (Onishi et al., 1979), cell surface protein from chick embryo fibroblasts (Olden et al., 1978) and influenza virus haemagglutinin (Schwarz \& Klenk, 1974). In all these reports the carbohydrate content linked through asparagine in the normal glycoprotein is said to vary from 10 to $16 \%$. In this respect one could compare the behaviour of the exo-1,3- $\beta$-D-glucanase to that shown by low carbohydrate-bearing glycoproteins.

The addition of oligosaccharides to the polypeptide chain takes place at the polyribosomal level (Ruiz-Herrera \& Sentandreu, 1975) and it seems reasonable to assume that the polypeptide folding occurs afterwards. The final conformation of the enzyme, and thus its catalytic activity, will be substantially influenced by the proportion of glycosidic residues. According to Onishi $e t$ al. (1979) the absence of glycosylation may reduce the thermodynamic advantage which normally would favour the folding into an active conformation; without such an advantage the folding to give a functional polypeptide must occur with a lower frequency. As exo-1,3- $\beta$-Dglucanase contains a low carbohydrate proportion linked to asparagine, the conformation of the polypeptide obtained in the presence of tunicamycin is probably different from that in the native enzyme. In this case, however, it still allows the underglycosylated polypeptide to develop its full catalytic power, since both native and underglycosylated forms of exo-1,3- $\beta$-D-glucanase exhibit similar $K_{\mathrm{m}}$ and activation energy values. The immunoprecipitation experiments also point to that conclusion since we were unable to detect an inactive exo-1,3- $\beta$-D-glucanase after treatment with tunicamycin. The underglycosylated enzyme produced by the endo $\mathrm{H}$ was very similar in molecular weight and carbohydrate content to the one obtained in the presence of tunicamycin. So, the lower stability of the latter could be attributed to incorrect protein folding because of the lack of carbohydrate.

From the results shown in Fig. 6 it may be inferred that some kind of exo-1,3- $\beta$-D-glucanase processing must exist. The existence of glycohydrolases in $S$. cerevisiae had already been reported by Kilker et al. (1981) and we have been able to detect mannosidases and glucosidases whose intracytoplasmic levels may vary according to the carbon source employed, and those presumably must be the enzymes involved in the different processing steps (unpublished results).

\section{REFERENCES}

Aminoff, D., Gathmann, W. D., Mclean, C. M. \& YADOMAE, T. (1980). Quantitation of oligosaccharides released by the $\beta$-elimination reaction. Analytical Biochemistry 101, 44-53.

Farkas, V. P., Biely, P. \& Bauer, S. (1973). Extracellular $\beta$-glucanases of the yeast Saccharomyces cerevisiae. Biochimica et biophysica acta 321, 246-255.

Garvey, J. S., Cremer, N. E. \& Sussdorf, D. H. 
(1977). Methods in Immunology, 3rd edn, pp. 313 335. Massachusetts: W. A. Benjamin.

Goldstein, I. J., Hay, G. W., Lewis, B. A. \& SMith, F. (1965). Controlled degradation of polysaccharides by periodate oxidation, reduction and hydrolysis. Methods in Carbohydrate Chemistry 5, 361369.

HickMAN, S. \& KorNFEld, S. (1978). Effect of tunicamycin on $\operatorname{IgM}, \operatorname{IgA}$ and $\operatorname{IgG}$ secretion by mouse plasmacytoma cells. Journal of Immunology 121, 990-996.

Hickman, S., KulCycky, A., LyNCh, R. G. \& KORNFELD, S. (1977). Studies on the mechanism of tunicamycin. Inhibition of $\operatorname{IgA}$ and $\operatorname{IgE}$ secretion by plasma cells. Journal of Biological Chemistry 253, 4402-4408.

Kilker, R. D., Saunier, B., Tkacz, J. S. \& HerscovICS, A. (1981). Partial purification from $S$. cerevisiae of a soluble glucosidase which removes the terminal glucose from the oligosaccharide $\mathrm{Glc}_{3} \mathrm{Man}_{9}$ GlcNAc $_{2}$. Journal of Biological Chemistry 256, 52995303.

Klenk, H., Christoph, S. \& Rott, R. (1972). Inhibition of glycoprotein biosynthesis of influenza virus by D-glucosamine and 2-deoxy-D-glucose. Viro$\log y$ 49, 723-734.

Kuo, S. C. \& Lampen, J. O. (1974). Tunicamycin, an inhibitor of yeast glycoprotein synthesis. Biochemical and Biophysical Research Communications 58, 287295.

Laurell, C. G. (1966). Quantitative estimation of proteins by electrophoresis in agarose gel containing antibodies. Analytical Chemistry 15, 45-50.

LlOYD, K. O. (1970). The preparation of two insoluble forms of the phytohemagglutinin Concanavalin A and their interactions with polysaccharides and glycoproteins. Archives of Biochemistry and Biophysics 137, 460-466.

Notario, V., Villa, T. G. \& Villanueva, J. R. (1976). Purification of an exo- $\beta$-D-glucanase from cell free extracts of Candida utilis. Biochemical Journal 159, 555-562.

Olden, K., Pratt, R. M. \& Yamada, K. M. (1978). Role of carbohydrates in protein secretion and turnover: effects of tunicamycin on the major cell surface glycoprotein of chick embryo fibroblasts. Cell 13, 461-473.

Onishi, H. R., Tkacz, J. S. \& Lampen, J. O. (1979). Glycoprotein nature of yeast alkaline phosphatase. Formation of active enzyme in the presence of tunicamycin. Journal of Biological Chemistry 254 11943-11952.

Ruiz-Herrera, J. \& Sentandreu, R. (1975). Site of initial glycosylation of mannoproteins from
Saccharomyces cerevisiae. Journal of Bacteriology 124, 127-133.

Sánchez, A., Larriba, G., Villanueva, J. R. \& Villa, T. G. (1980). Glycosylation is not necessary for the secretion of exo-1,3- $\beta$-D-glucanase by Saccharomyces cerevisiae protoplasts. FEBS Letters 121, 283-286.

Schultz, A. M. \& Oroszlan, S. (1979). Tunicamycin inhibits glycosylation of precursor polyprotein encoded by env gene of Rauscher murine leukemia virus. Biochemical and Biophysical Research Communications 86, 1206-1213.

SCHWARZ, R. T. \& KLENK, H. D. (1974). Inhibition of glycosylation of the influenza virus hemagglutinin. Journal of Virology 14, 1023-1034.

SCHWARZ, R. T., RohrSChNeIDER, J. M. \& SCHMidT, M. F. G. (1976). Suppression of glycoprotein formation of semliki forest influenza and avian sarcoma virus by tunicamycin. Journal of Virology 19, 782791.

Takatsuki, A., Arima, K. \& Tamura, G. (1971). Tunicamycin, a new antibiotic. I. Isolation and characterization of tunicamycin. Journal of Antibiotics 24, 215-223.

Tarentino, A. L.. Plummer, JR, T. H. \& Maley, F. (1974). The release of intact oligosaccharides from specific glycoproteins by endo- $\beta-N$-acetylglucosaminidase H. Journal of Biological Chemistry 249, 818-824.

TKaCZ, J. S. \& Lampen, J. O. (1975). Tunicamycin inhibition of polyisoprenol- $N$-acetyl-glucosaminyl phosphatase formation in calf-liver microsomes. Biochemical and Biophysical Research Communications 65, 248-257.

Villa, T. G., Notario, V. \& Villanueva, J. R. (1978a). Direct chemical proof of different glycosylation patterns for yeast exo- and endo-1,3- $\beta$-Dglucanases. Journal of General Microbiology 109, 371374.

Villa, T. G., Lachance, M. A. \& PhafF, H. J. $(1978 b) . \beta$-Glucanases of the yeast Kluyveromyces phaseolosporus: partial purification and characterization. Experimental Mycology 2, 12-25.

Villanueva, J. R., Notario, V., Santos, T. \& Villa, T. G. (1976). $\beta$-Glucanases in nature. Biochemistry and function of $\beta$-glucanases in yeast. In Proceedings in the 4th International Symposium on Yeast and other Protoplasts, pp. 323-355. Edited by J. F. Peberdy, A. H. Rous \& H. J. Rogers. London \& New York: Academic Press.

Zaccharius, R. M., Zell, T. E., Morrison, J. H. \& WOODLOCK, J. J. (1969). Glycoprotein staining following electrophoresis on acrylamide gels. Analytical Biochemistry 30, 148-152. 